\title{
Evaluation of the paediatric dose of chloroquine in the treatment of Plasmodium vivax malaria
}

\author{
Arletta Añez ${ }^{1 *}$, Manuel Moscoso ${ }^{2}$, Cecilia Garnica ${ }^{2}$ and Carlos Ascaso ${ }^{3}$
}

\begin{abstract}
Background: Chloroquine (CQ) continues to be the first-line medication used worldwide in the treatment of Plasmodium vivax malaria. The dose recommended by the World Health Organization is $25 \mathrm{mg} / \mathrm{kg}$ independently of the age of the subject. Nonetheless, the pharmacokinetics and pharmacodynamics of drugs in children are different from those in adults and may influence the drug concentrations in blood and become risk factors for therapeutic failure and/o resistance to CQ.

Methods: This study is a secondary analysis of the data from a clinical trial in which children over 5 years of age were administered $25 \mathrm{mg} / \mathrm{kg}$ of CQ, and CQ concentrations in blood were measured at day 7 of follow-up. Models of regression and comparison were used to evaluate and compare the CQ dose taken per $\mathrm{kg} / \mathrm{body}$ weight, the CQ dose calculated based on body surface area, CQ levels in blood on day 7 and the age of the population.

Results: The younger the study population the greater the difference between the dose per kg/body weight (real dose) and that calculated according to the BSA (theoretical dose). The difference between the two doses was $-181.206 \mathrm{mg}$ in the $5-9$ years of age group (Cl $95 \%-195.39 ;-167.02 \mathrm{mg})$ and $-71.39 \mathrm{mg}$ (Cl $95 \%-118.61$; $-23.99 \mathrm{mg}$ ) in the 10-14-year-old group. The CQ concentrations in blood on day 7 differed in patients over and under 15 years ( $p=0.008$ ). A negative correlation was found between the real and theoretical dose (difference in dose) and the age in years $(R 2=0.529, p=0.001)$. A negative correlation was also found between the difference in dose $(\mathrm{mg})$ and CQ concentrations on day $7(\mathrm{ng} / \mathrm{ml})(r=-0.337, \mathrm{p}=0.001)$. Children under 15 years were found to have a higher rate of therapeutic failure than those over 15 (28 vs $4.2 \%$, respectively) (Kaplan-Meier $p=0.005$ ).

Conclusions: A CQ dose of $25 \mathrm{mg} / \mathrm{kg}$ for the treatment of P. vivax malaria may be too low in children as demonstrated by the reduction in CQ concentrations in blood at day 7 of follow-up. This under-dosage is probably associated with the higher rate of therapeutic failure found in children under 15 years (28 vs $4.3 \%$ ). These results suggest the need to review the paediatric doses of CQ currently used.
\end{abstract}

Keywords: Chloroquine, Paediatric doses, Chloroquine in children

\section{Background}

Vivax malaria continues to be an important health problem worldwide. It is estimated that this parasite caused 13.8 million cases throughout the world in 2015 and contributed to almost half of the cases of malaria reported outside of Africa. In South America, Plasmodium vivax

\footnotetext{
*Correspondence: arlettarocio@gmail.com

${ }^{1}$ Departamento de Salud Pública, Universidad de Barcelona, Barcelona, Spain

Full list of author information is available at the end of the article
}

causes $70 \%$ of the total number of cases of malaria [1]. Despite the progressive resistance of Plasmodium falciparum to chloroquine (CQ) $[2,3]$, this drug continues to be the medication of choice in the treatment of malaria by $P$. vivax and special cases of malaria [4].

Recognition of the value of CQ occurred late, and this medication was not used until 1946 [5] after having been re-evaluated by the armed forces of the United States for its use against vivax malaria and later for falciparum malaria. The initial studies were carried out in military 
personnel infected with $P$. vivax at a dose of $1.5 \mathrm{~g}$ during four days [6]. The dose recommended by the World Health Organization (WHO) continues to be $25 \mathrm{mg} / \mathrm{kg}$ of body weight $(\mathrm{BW})$, divided into three daily doses (1.5 $\mathrm{g}$ in patients of $60 \mathrm{~kg}$ ) independently of the age of the patient [7].

CQ is completely absorbed through the gastrointestinal tract and its maximum concentration is achieved $1-3 \mathrm{~h}$ after oral ingestion, with $60 \%$ of the drug binding to plasma proteins [8]. After the ingestion of a single oral dose CQ concentrations in whole blood are approximately tenfold greater than those in plasma. Following absorption, CQ is distributed throughout the body and accumulates in the organs, especially the liver, lungs, spleen and kidneys [9]. The CQ distribution volume (DV) is very large $(>200 \mathrm{l} / \mathrm{kg})$, and it rapidly de-alkyates through the cytochrome P450 (CYP) enzymes into pharmacologically active desethylchloroquine (DCQ) and bisdesethylchloroquine. The mean half-life of the drug is from 35 to 40 days after ingestion [10]. The minimum effective concentration (MEC) of the drug in whole blood is $75-150 \mathrm{ng} / \mathrm{ml}$, and, from the most conservative point of view, a CQ + DCQ concentration $>100 \mathrm{ng} / \mathrm{ml}$ in the presence of parasite growth is considered as resistance [11-13].

Breastfeeding infants and children under many changes along their development in regard to the absorption, distribution, metabolism and excretion of drugs, presenting important pharmacokinetic and pharmacodynamic differences compared to adults $[14,15]$. Indeed, these physiological factors may influence the availability of drugs in the organism particularly with respect to body composition as well as extracellular and total body water, fat distribution and muscle mass [16]. Therefore, it has been recommended that drugs should be administered to children according to their body surface area (BSA) $[17,18]$.

This wide variation in systemic exposure to drug concentrations has a significant effect on the effective drug concentrations achieved within the body. Suboptimal or low CQ concentrations in blood increase the risk of therapeutic failure and the appearance and spread of resistant strains of Plasmodium [19-23].

In many studies on the therapeutic efficacy of CQ the rates of therapeutic failure and drug resistance were greater in children than in adults [24-28]. However, no evidence has shown that therapeutic failure in these cases is caused by suboptimal doses of CQ.

On the other hand, the lack of acquired immunity in children affects the spread of resistance to anti-malarial drugs [29], although this seems to be more related to infants [30]. In this respect recent reports have shown that paediatric doses of anti-malarial drugs should be reevaluated [31, 32].
The aim of this study was to evaluate whether the standard CQ dose of $25 \mathrm{mg} / \mathrm{kg}$ achieves the same CQ concentrations in blood of children and adults diagnosed with vivax malaria.

\section{Methods}

This study is a secondary analysis of the data of a clinical trial on the therapeutic response of CQ in infection by $P$. vivax [33]. The analysis was carried out from May to November 2011 in the Amazonic area of RiberaltaBolivia, which has a medium high level of endemicity [34].

The inclusion criteria were: patients over 5 years of age diagnosed with mono parasitaemia by $P$. vivax, with a parasite density of asexual forms of $250-100,000$ parasites/ $\mu \mathrm{l}$. The exclusion criteria were: pregnancy, signs and symptoms of severe malaria, history of allergy to antimalarial drugs, concomitant severe or chronic diseases such as tuberculosis or HIV/AIDS, and previous treatment with other anti-malarial drugs.

All the patients were given scored tablets of CQ (Lote FCV 002A, Macleods Pharmaceuticals Ltd., India) at a dose of $25 \mathrm{mg} / \mathrm{kg}$, divided into three daily doses: $10 \mathrm{mg} /$ $\mathrm{kg}$ on days 1 and 2 and $5 \mathrm{mg} / \mathrm{kg}$ on day 3 . Patients presenting vomiting half-an-hour after drug administration were given a new treatment cycle with the same dose, and patients with two new vomiting episodes were excluded from the study. Drug administration was strictly supervised by the study personnel, and dosing strategies based on age bands were not used.

The patients included in the study were followed over 28 days with 5 clinical and laboratory evaluations according to WHO guidelines for the assessment of therapeutic efficacy [13]. Data regarding the height, weight and BSA of all the patients were collected at admission. CQ and DCQ concentrations in whole blood were determined using high performance liquid chromatography (HPLC) at days 7 and 28 of follow-up. At day 28 of follow up all the patients were given oral primaquine (PQ) $0.5 \mathrm{mg} / \mathrm{kg}$ during 7 days according to the treatment schedule of the malaria program of Bolivia. Patients presenting therapeutic failure or found to have mixed malaria were treated with an alternative schedule and excluded from the study.

\section{Statistical analysis}

The BSA was calculated using the Boyd formula $\left(\mathrm{m}^{2}\right)=0.0003207 \times$ height $(\mathrm{cm}) 0.3 \times$ weight $(\mathrm{g})$ $0.7285-[0.0188 \times \log ($ weight $)]$ [35], and the dose of CQ in $\mathrm{mg} / \mathrm{m}^{2}$ according to BSA was calculated using the formula (BSA/1.73) $\times 1500$ (adult dose) [17]. These variables were compared with CQ blood concentrations at day 7 of follow up [36]. 
Table 1 Characteristics: weight, BSA, CQ real-dose, CQ theoretical dose, and blood concentrations of CQ on day 7 of follow-up in each group

\begin{tabular}{|c|c|c|c|c|c|c|}
\hline $\begin{array}{l}\text { Age group } \\
\text { (years) }\end{array}$ & $\begin{array}{l}\text { Number } \\
\text { records }\end{array}$ & Weight (kg) & $\operatorname{BSA}^{a}\left(m^{2}\right)$ & $C Q$ real dose ${ }^{b}(\mathrm{mg})$ & $\begin{array}{l}\text { CQ theoretical } \\
\operatorname{dose}^{c}\left(m^{2}\right)\end{array}$ & $\mathrm{CQD7}^{\mathrm{d}}(\mathrm{ng} / \mathrm{ml})$ \\
\hline $5-9$ & 10 & 21.15 (SD 5.02) & 0.83 (SD 0.13) & 536.50 (SD 120.69) & 717.71 (SD 112.48) & 235.47 (SD 69.92) \\
\hline $10-14$ & 14 & 42.92 (SD 9.02) & 1.33 (SD 0.18) & 1085.50 (SD 231.58) & 1156.80 (SD 156.32) & 308.20 (SD 89.69) \\
\hline $15-24$ & 36 & 61.42 (SD 9.48) & 1.68 (SD 0.15) & 1542.81 (SD 239.85) & 1458.84 (SD 133.87) & 342.72 (SD 165.28) \\
\hline $25-34$ & 14 & 62.12 (SD 12.60) & 1.68 (SD 0.20) & 1562.29 (SD 322.06) & $1460.28(S D$ 174.16) & 455.35 (SD 137.86) \\
\hline $35-44$ & 11 & 71.32 (SD 12.94) & 1.83 (SD 0.19) & 1782.82 (SD 323.69) & 1589.72 (SD 162.42) & 395.02 (SD 199.02) \\
\hline $45-54$ & 6 & 64.67 (SD 8.74) & 1.74 (SD 0.13) & 1604.08 (SD 238.12) & 1510.06 (SD 115.54) & 384.57 (SD 51.47) \\
\hline $55-65$ & 4 & 69.75 (SD 13.60) & 1.80 (SD 0.21) & 1745.00 (SD 342.08) & 1564.96 (SD 183.79) & 391.20 (SD 94.90) \\
\hline
\end{tabular}

CQ chloroquine, $D C Q$ desethylchloroquine, $S D$ standard deviation

a $B S A$ in $\mathrm{m}^{2}=$ body surface area calculated using the Boyd formula

BSA $\left(\mathrm{m}^{2}\right)=0.0003207 \times$ height $(\mathrm{cm}) 0.3 \times$ weight $(\mathrm{g}) 0.7285-[0.0188 \times \log ($ weight $)]$

b $\mathrm{CQ}$ real dose: $\mathrm{CQ}$ taken in $\mathrm{mg} / \mathrm{kg} /$ weight

' $\mathrm{CQ}$ theoretical dose: $\mathrm{CQ}$ dose according to: (BSA/1.73)*1500 (adult dose)

${ }^{d}$ CQD7: CQ + DCQ on day 7 of follow-up

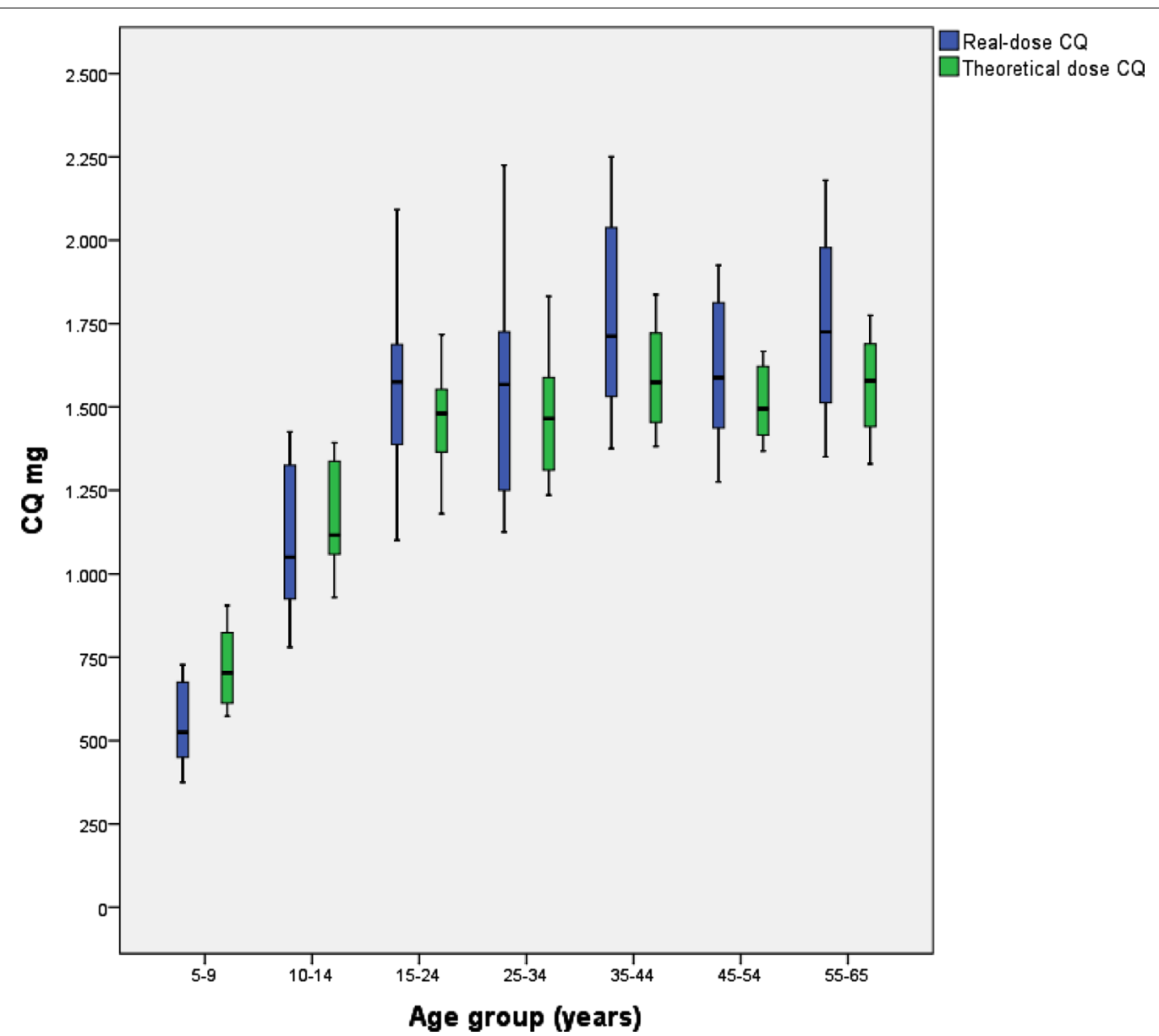

Fig. 1 Description of chloroquine ( $\mathrm{mg}$ ) taken in $\mathrm{mg} / \mathrm{kg}$ (real dose) and dose calculated as $\mathrm{mg} / \mathrm{m}^{2}$ body surface area (BSA) (theoretical dose) by age group 
The statistical package SPSS ${ }^{\circledR} 21$ (Chicago, IL, USA) was used to describe and express the variables studied. The normality of the quantitative variables and the residual values of the regression models were evaluated using a QQ-plot. Associations among variables were analysed by comparison of means using the Chi square or Fisher's exact test and adjusting the linear or curvilinear regressions. Kaplan-Meier analysis was used to estimate the rate of therapeutic failure. Estimations were made using a $95 \%$ confidence interval (CI), and all contrasts of hypothesis were evaluated with an alpha risk of $5 \%$.

\section{Results}

A total of 96 patients diagnosed with P.vivax malaria were administered CQ at $25 \mathrm{mg} / \mathrm{kg}$ and CQ + DCQ concentrations in blood were assessed at day 7 of follow up. The details of the therapeutic evaluation have been described elsewhere [33]. One patient was excluded for having atypical height and weight values.

Table 1 shows the characteristics of the patients in each group including: weight, BSA, CQ dose in $\mathrm{mg} / \mathrm{kg}$ (real dose), CQ dose calculated in $\mathrm{mg} / \mathrm{m}^{2}$ of BSA (theoretical dose), and CQ + DCQ concentrations in blood on day 7 of follow up (CQD7).
Figure 1 shows the description of the real and the theoretical CQ dose (mg) by age group. Statistically significant differences were found between the two doses $(p=0.001)$. In the age groups of 5-9 and 10-14 years the real CQ dose was lower than the theoretical dose, being $-181.206 \mathrm{mg}$ (CI $95 \%-195.39 ;-167.02 \mathrm{mg})$ and $-71.30 \mathrm{mg}(\mathrm{CI} 95 \%-118.61 ;-23.99 \mathrm{mg})$, respectively.

In contrast, the real CQ dose in patients over 15 years of age was greater than the theoretical CQ dose, with the difference between the two doses being $114.91 \mathrm{mg}$ (CI $95 \% 82.64 ; 147.16 \mathrm{mg})$.

On analysing the variable "Difference in dose" defined as the difference between the real and theoretical dose, it was found that the younger the study population the larger the difference. Figure 2 shows a logistic model of the relationship of the difference in $\mathrm{mg}$ of the two doses and the age $(\mathrm{R} 2=0.529, \mathrm{p}=0.001)$. The difference between the two doses was negative in patients under 15 years of age and could be interpreted as under dosing of CQ compared to the theoretical dose, while the difference was equal to or positive in patients over 15 years.

Figure 3 describes the CQ concentrations on day 7 (CQD7) by age group. These concentrations were found

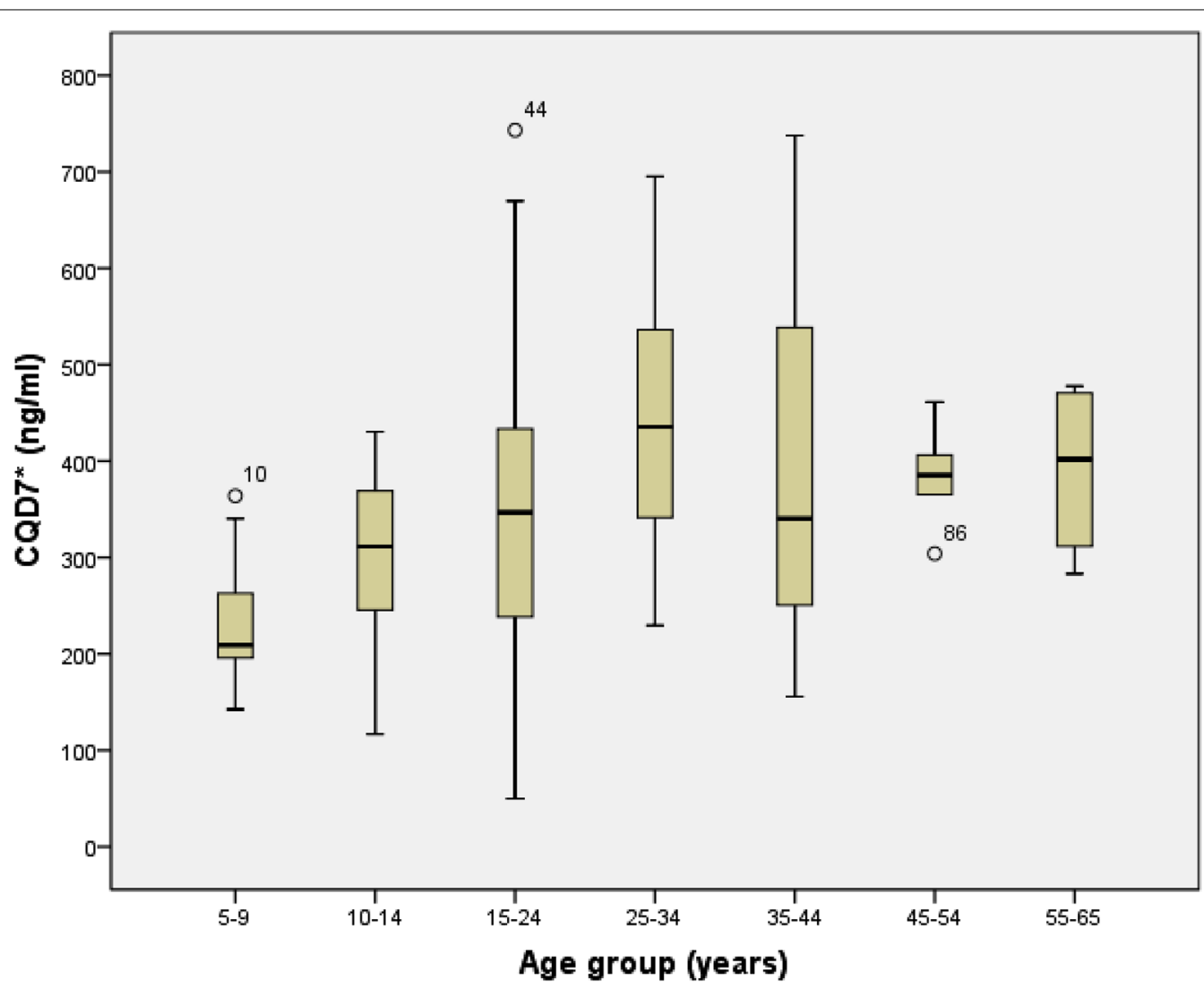

Fig. 2 CQD7 (ng/ml) description and analysis by age group. ${ }^{*}$ CQD7 ( $\left.\mathrm{ng} / \mathrm{ml}\right): \mathrm{CQ}+\mathrm{DCQ}$ on day 7 of follow up 


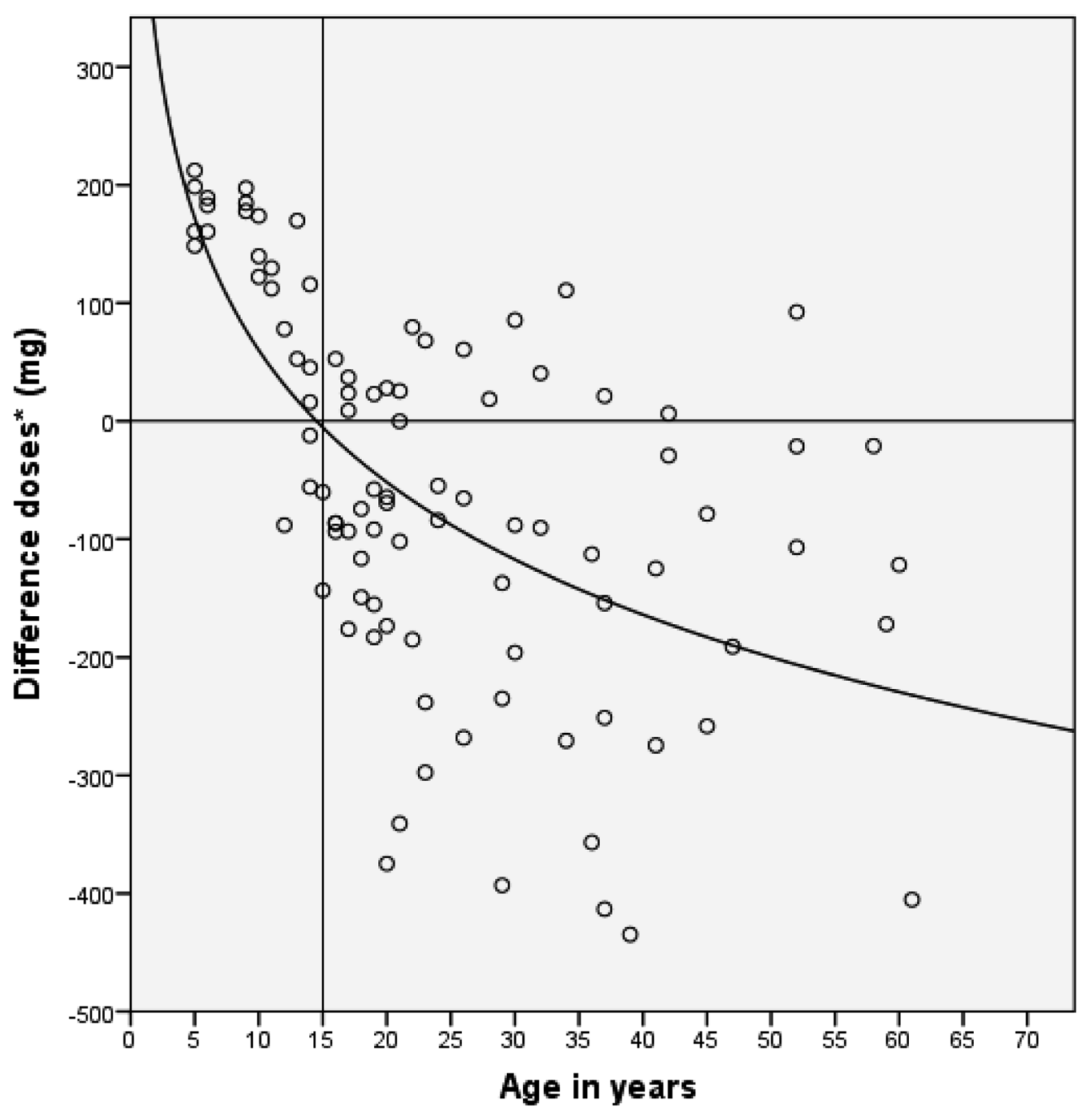

Fig. 3 Correlation between the different doses of chloroquine $(\mathrm{mg})$ and patient age (years). * Difference in doses (mg): difference between dose taken in $\mathrm{mg} / \mathrm{kg} /$ weight and that calculated as $\mathrm{mg} / \mathrm{m}^{2}$ of body surface area (BSA)

to be lower in children under 15 years of age compared to those over this age, with a mean difference of $-101.40 \mathrm{ng} /$ $\mathrm{ml}(\mathrm{p}=0.008)$. Indeed, the difference was even greater in the group from 5-9 years of age compared to those over the age of 15 , being $-143.831 \mathrm{ng} / \mathrm{ml}(\mathrm{p}=0.033)$.

In relation to the difference between the real and theoretical dose of $C Q$, it was observed that the lower the real dose the lower the CQD7 values and the greater the difference with the theoretical dose. That is, a negative correlation was found between the difference of the dose $(\mathrm{mg})$ and the CQD7 $(\mathrm{ng} / \mathrm{ml})(\mathrm{r}=-0.337, \mathrm{p}=0.001)$ (Fig. 4).

On the other hand, of the 95 patients who fulfilled the criteria of normality, nine presented therapeutic failure: 1 on day 7, 2 on day 21 and 6 on day 28 of follow up. The mean age of the patients with therapeutic failure was 14.78 years and that of patients who were cured was 25.20 years $(\mathrm{p}=0.03)$.

On analysing therapeutic failure in relation to age group, the rate of therapeutic failure was found to $28 \%$ in the groups younger than 15 and $4.2 \%$ in the group greater than or equal to 15 years of age (Kaplan-Meier $\mathrm{p}=0.005)$.

\section{Discussion}

The real and theoretical doses of $\mathrm{CQ}$ are different and vary with age $(\mathrm{p}=0.001)$. The greatest difference was found in the 5-9 year age group followed by the 10-14-year-old group. On average these groups were administered -181.20 and $-71.30 \mathrm{mg}$, respectively of 


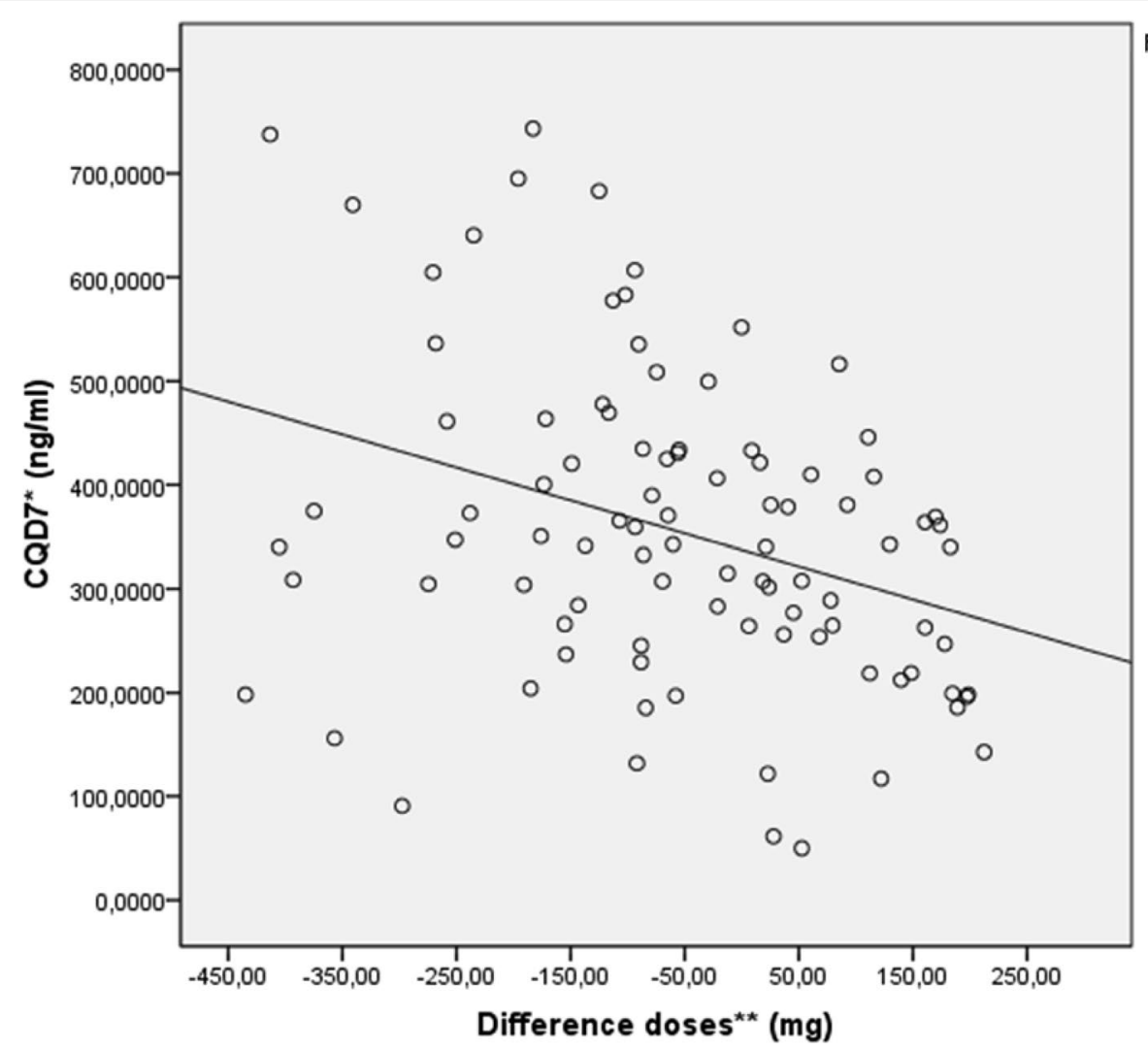

Fig. 4 Correlation between the different doses of chloroquine $(\mathrm{mg})$ and chloroquine blood concentrations (ng/ml). ${ }^{*} \mathrm{CQD} 7(\mathrm{ng} / \mathrm{ml}): \mathrm{CQ}+\mathrm{DCQ}$ on day 7 of follow up. **Difference in doses (mg): difference between dose taken in $\mathrm{mg} / \mathrm{kg} /$ weight and that calculated as $\mathrm{mg} / \mathrm{m}^{2}$ of body surface area (BSA)

CQ. To the contrary, patients over 15 years of age are prescribed more than they actually need with $114.91 \mathrm{mg}$. The relationship between the difference of the two doses and the age was adjusted in a logarithmic model and showed that the younger the age of the individual treated the lower the quantity of CQ prescribed.

With the dose of $25 \mathrm{mg} / \mathrm{kg}$ of body weight at diagnosis of $P$. vivax malaria, CQ concentrations in blood on day 7 of follow up were also lower in the youngest age group. The 5-9 years of age group was given an average of $143.831 \mathrm{mg} / \mathrm{ml}$ less than patients older than 15 years. These results are similar to those reported by Ringwald et al. [37] who suggested that this could be due to an accelerated elimination of the drug in children.

Using doses of 25 and $50 \mathrm{mg} / \mathrm{kg}$ of CQ in children under 15 years of age with $P$. falciparum malaria, Ursing et al. [32] also found that the younger the patients the lower the CQ concentrations at day 7.

Some authors have described the need to take into account that the renal and liver function, metabolic rate, total body and extracellular water, body fat distribution and muscle mass are different in children compared to adults $[14,16,38]$. This could probably explain the differences associated with drug absorption, distribution, metabolism and excretion in children which lead to altered pharmacokinetics and may be the reason for the low CQ concentrations observed on day 7.

Previous studies using allometric scaling models have shown that the cause of the lowest CQ concentrations is probably due to under dosing [39, 40]. In this study it was also observed that the lower the age the greater the difference of the real and theoretical doses. A negative correlation was also found between the real and the theoretical dose of CQ calculated and age, and it was shown that the greater the difference in the dose the lower the CQ concentrations in blood on day 7 of follow up, suggesting under dosing of CQ in children.

The association of the low level of CQ on day 7 found in children under 15 years and the rate of therapeutic failure of $28 \%$ in this same group versus $4.2 \%$ in subjects over 15 years may help to interpret these results as suboptimal dosage of CQ in children under 15 years of age. 
These findings suggest the need to consider adjusting the paediatric doses of $\mathrm{CQ}$. Some authors recommend the dose be increased between 35 and $50 \mathrm{mg} / \mathrm{kg}$ in children in order to achieve the same CQ concentrations on day 7 of follow up as those of adults [32, 40]. Indeed, several studies have shown that doses of up to $50 \mathrm{mg} / \mathrm{kg}$ of CQ can be given to children less than 15 years of age with the same adverse effects as those of a dose of $25 \mathrm{mg} / \mathrm{kg}$ [39, 41, 42].

\section{Conclusion}

The standard dose of CQ of $25 \mathrm{mg} / \mathrm{kg}$ in the treatment of $P$. vivax malaria may be suboptimal in children under 15 years of age. This under-dosage may be related to a reduction in CQ concentrations found in blood on day 7 of follow up, with younger children showing greater reductions. Indeed, the rate of therapeutic failure in children under 15 is greater than that in patients over this age probably due to this insufficient CQ doses in these patients.

Since suboptimal drug concentrations increase the risk of therapeutic failure and/or drug resistance, paediatric doses of CQ for the treatment of P. vivax malaria should be re-evaluated for each age group [23].

\section{Authors' contributions}

AA designed, coordinated and wrote the article, CG and MM determined the chloroquine concentrations in blood. CA performed the statistical analyses and revised the writing of the article. All authors read and approved the final manuscript.

\section{Author details}

1 Departamento de Salud Pública, Universidad de Barcelona, Barcelona, Spain. ${ }^{2}$ Laboratorio de Control de Calidad de Medicamentos y Toxicología del Instituto Nacional de Laboratorios en Salud. CONCAMYT-INLASA, La Paz, Bolivia. ${ }^{3}$ Departamento de Salud Pública, Universidad de Barcelona. Institut d' Investicions Biomediques, Augusto Pi i Sunyer, Barcelona, Spain.

\section{Acknowledgements \\ This study was developed in part thanks to support from the Laboratory of Quality Control and Medications of the Instituto Nacional de Laboratorios en Salud (INLASA) and the Pan-American Health Organization, Bolivia. We would like to thank Mr. Angel Laguna, Mrs. Viviana Melgar, Dra. Mauren Cuba, Dra. Sonia Gutierrez for their support in the development of the original article.}

\section{Competing interests}

The authors declare that they have no competing interests.

\section{Availability of data and materials}

The database may not be available, because it is owned by Pan-American Organization of Health.

\section{Consent for publication}

All patients participated voluntarily and provided signed informed consent for evaluation of the therapeutic efficacy of the drug and the use of the results in another type of evaluation. In the cases of under-age participants, informed consent was provided by their legal guardians.

\section{Ethics approval and consent to participate}

The study was performed according to the recommendations of the National Bioethics Committee of Bolivia and the Ethical Committee of the Pan-American Organization of Health (PAHOERC).

Received: 22 April 2016 Accepted: 4 July 2016

Published online: 19 July 2016
References

1. WHO. World malaria report. Geneva: World Health Organization; 2015.

2. Trape JF. The public health impact of chloroquine resistance in Africa. Am J Trop Med Hyg. 2001;64(Suppl 1-2):12-7.

3. Wellems TE, Plowe CV. Chloroquine-resistant malaria. J Infect Dis. 2001;15:770-6.

4. Naing C, Aung K, Win DK, Wah MJ. Efficacy and safety of chloroquine for treatment in patients with uncomplicated Plasmodium vivax infections in endemic countries. Trans R Soc Trop Med Hyg. 2010;104:695-705.

5. Loeb F, Clark WM, Coatney GR, Coggeshall LT, Dieuaide FR, Dochez AR, et al. Activity of a new antimalarial agent, chloroquine. J Am Med Assoc. 1946;130:1069-70.

6. Most H, London IM, Kane CA, Lavietes PH, Schroeder EF, et al. Chloroquine for treatment of acute attacks of vivax malaria. J Am Med Assoc. 1946;131:963-7.

7. WHO. Guidelines of the treatment of malaria. 3rd ed. Geneva: World Health Organization; 2015.

8. Ducharme J, Farinotti R. Clinical pharmacokinetics and metabolism of chloroquine. Focus on recent advancements. Clin Pharmacokinet. 1996;31:257-74.

9. Litter M. Compendio de farmacología. 4rta ed. Buenos Aires: El Ateneo; 1998. p. 794-805.

10. Browning DJ. Pharmacology of chloroquine and hydroxychloroquine 2: hydroxychloroquine and chloroquine retinopathy. New York: Springer; 2014. p. 44-8

11. Baird JK, Leksana B, Masbar S, Fryauff DJ, Sutanihardja MA, Suradi, et al. Diagnosis of resistance to chloroquine by Plasmodium vivax: timing of recurrence and whole blood chloroquine levels. Am J Trop Med Hyg. 1997;56:621-6.

12. Baird JK. Chloroquine resistance in Plasmodium vivax. Antimicrob Agents Chemother. 2004;11:4075-83.

13. WHO. Methods for surveillance of antimalarial drug efficacy. Geneva: World Health Organization; 2009.

14. Kearns GL, Abdel-Rahman SM, Alander SW, Blowey DL, Leeder JS, Kauffman RE. Developmental pharmacology-drug disposition, action, and therapy in infants and children. N Engl J Med. 2003;349:1157-67.

15. Strolin Benedetti M, Baltes EL. Drug metabolism and disposition in children. Fundam Clin Pharmacol. 2003;17:281-99.

16. Friss-Hansen B. Body water compartments in children; changes during growth and related changes in body composition. Pediatrics. 1961;28:169-81.

17. Peiré MA. SituacionesFisiológicasquemodifican la respuesta II: elniño. In Farmacologíabásica y Clínica de Velazquez. décimooctava ed. Madrid: Medica Panamericana; 2008. p.1132.

18. Orimadegun A, Omisanjo A. Evaluation of five formulae for estimating body surface area of Nigerian Children. Ann Med Health Sci Res. 2014;4:889-98

19. Mockenhaupt FP, May J, Bergqvist Y, Ademowo OG, Olumese PE, Falusi $A G$, et al. Concentrations of chloroquine and malaria parasites in blood in Nigerian children. Antimicrob Agents Chemother. 2000;44:835-9.

20. Hellgren U, Ericsson O, Kihamia CM, Rombo L. Malaria parasites and chloroquine concentrations in Tanzanian schoolchildren. Trop Med Parasitol. 1994:45:293-7.

21. WHO. Drug resistance in malaria. Geneva: World Health Organization; 2001.

22. Gbotosho GO, Happi CT, Ganiyu A, Ogundahunsi OA, Sowunmi A, Oduola AM. Potential contribution of prescription practices to the emergence and spread of chloroquine resistance in south-west Nigeria: caution in the use of artemisinin combination therapy. Malar J. 2009;8:313.

23. Barnes Kl, Watkins WM, White NJ. Antimalarial dosing regimens and drug resistance. Trends Parasitol. 2008;24:127-34.

24. Ruebush TK, Zegarra J, Cairo J, Andersen EM, Green M, Pillai DR, et al. Chloroquine-resistant Plasmodium vivax malaria in Peru. Am J Trop Med Hyg. 2003;69:548-52.

25. Ketema T, Bacha K, Birhanu T, Petros B. Chloroquine-resistant Plasmodium vivax malaria in Serbo town, Jimma zone, south-west Ethiopia. Malar J. 2009;8:177

26. Teka H, Petros B, Yamuah L, Tesfaye G, Elhassan I, Muchohi S, et al. Chloroquine-resistant Plasmodium vivax malaria in Debre Zeit, Ethiopia. Malar J. 2008;7:220. 
27. Murphy GS, Basri H, Purnomo Andersen EM, Bangs MJ, Mount DL, et al. Vivax malaria resistant to treatment and prophylaxis with chloroquine. Lancet. 1993;9:96-100.

28. Yeshiwondim AK, Tekle AH, Dengela DO, Yohannes AM, Teklehaimanot A. Therapeutic efficacy of chloroquine and chloroquine plus primaquine for the treatment of Plasmodium vivax in Ethiopia. Acta Trop. 2010;113:105-13.

29. Travassos Mark A, Laufer Miriam K. Resistance to antimalarial drugs: molecular, pharmacological and clinical considerations. Pediatr Res. 2009;65:64R-70R.

30. Djimdé AA, Doumbo OK, Traore O, Guindo AB, Kayentao K, Diourte Y, et al Clearance of drug-resistant parasites as a model for protective immunity in Plasmodium falciparum malaria. Am J Trop Med Hyg. 2003;69:558-63.

31. Siqueira AM, Coutinho LI, Gurgel RL, Su WC, Carvalho LM, Benzecry SG, et al. Slow clearance of Plasmodium vivax with chloroquine amongst children younger than six months of age in the Brazilian Amazon. Mem Inst Oswaldo Cruz. 2014;109:540-5.

32. Ursing J, Eksborg S, Rombo L, Bergqvist Y, Blessborn D, Rodriges A, et al. Chloroquine is grossly under dosed in young children with malaria: implications for drug resistance. PLoS ONE. 2014;9:e86801.

33. Añez A, Moscoso M, Laguna Á, Garnica C, Melgar V, Cuba M, et al. Resistance of infection by Plasmodium vivax to chloroquine in Bolivia. Malar J. 2015;14:261.

34. Ministerio de Salud y Deportes, Programa Nacional de malaria. Situación Actual de la malaria en Bolivia. Parte Epidemiológico, La Paz; 2011.

35. Boyd E. The growth of the surface area of the human body. Institute of Child Welfare, Monograph Series 10. University of Minnesota; 1935.
36. White NJ, Stepniewska K, Barnes K, Price RN, Simpson J. Simplified antimalarial therapeutic monitoring: using the Day 7 drug level? TrendsParasitol. 2008;24:159-63.

37. Ringwald P, Same Ekobo A, Keundjian A, Kedy Mangamba D, Basco LK. Chimiorésistance de $P$. falciparum en milieu urbain à Yaoundé, Cameroun. Part 1: surveillance in vitro et in vivo de la résistance de Plasmodium falciparum à la chloroquine entre 1994 et 1999 à Yaoundé, Cameroun. Trop Med Int Health. 1994;2000(5):612-9.

38. Kearns GL. Impact of developmental pharmacology on pediatric study design: overcoming the challenges. J Allergy Clin Immunol. 2000;106(Suppl 1):128-38.

39. Obua C, Hellgren U, Ntale M, Gustafsson LL, Ogwal-Okeng JW, Gordi T, et al. Population pharmacokinetics of chloroquine and sulfadoxine and treatment response in children with malaria: suggestions for an improved dose regimen. Br J Clin Pharmacol. 2008;65:493-501.

40. Moore BR, Page-Sharp M, Stoney JR, Ilett KF, Jago JD, Batty KT. Pharmacokinetics, pharmacodynamics, and allometric scaling of chloroquine in a murine malaria model. Antimicrob Agents Chemother. 2011;55:3899-907.

41. Ursing J, Kofoed PE, Rodrigues A, Bergqvist Y, Rombo L. Chloroquine is grossly overdosed and overused but well tolerated in Guinea-Bissau. Antimicrob Agents Chemother. 2009;53:180-5.

42. Kofoed PE, Ursing J, Poulsen A, Rodrigues A, Bergquist $Y$, Aaby $P$, et al. Different doses of amodiaquine and chloroquine for treatment of uncomplicated malaria in children in Guinea-Bissau: implications for future treatment recommendations. Trans R Soc Trop Med Hyg. 2007;101:231-8.

\section{Submit your next manuscript to BioMed Central and we will help you at every step:}

- We accept pre-submission inquiries

- Our selector tool helps you to find the most relevant journal

- We provide round the clock customer support

- Convenient online submission

- Thorough peer review

- Inclusion in PubMed and all major indexing services

- Maximum visibility for your research

Submit your manuscript at www.biomedcentral com/submit 